\title{
Effects of Some Xenobiotics on the Disposition of Brain Serotonin and Catecholamine in Rats ${ }^{\dagger}$
}

\author{
Hidehiko Yokogoshi* \\ Laboratory of Nutritional Biochemistry, School of Food and \\ Nutritional Sciences, The University of Shizuoka, \\ Shizuoka 422, Japan \\ Received January 9, 1989
}

\begin{abstract}
Exposure to some xenobiotics (pentobarbital, 3-tert-butyl-4-methoxyphenol (BHA), chloretone (acetone chloroform), 1,1-bis-( $p$-chlorophenyl)-2,2,2-trichloroethane (DDT) and polychlorinated biphenyls (PCB)) for a $5 \mathrm{hr}$ period increased the concentrations of brain serotonin and 5-hydroxyindole acetic acid (5HIAA). The decrease in the brain serotonin level elicited by p-chlorophenylalanine (PCPA), an inhibitor of serotonin synthesis, was prevented by the concomitant administration of chloretone. The administration of both chloretone and pargyline (an inhibitor of monoamine oxidase) caused significant elevation of the brain 5HIAA level as compared with that in a pargyline control, however, the concentration of brain serotonin was not different between pargyline alone and chloretone plus pargyline. These results show that the increase in the brain serotonin level caused by chloretone is not due to acceleration of brain serotonin synthesis, but to retardation of the degradation of brain serotonin, and the increase in brain 5HIAA caused by chloretone may be due to the reduced removal of 5HIAA from the brain. Chloretone plus pargyline caused significant elevation of hypothalamus catecholamines, as compared to in the pargyline control, so the catecholamine turnover rates may be accelerated by the administration of chloretone.
\end{abstract}

We recently provided biochemical evidence of changes in the levels of brain 5-hydroxyindoles (such as serotonin and 5-hydroxyindole acetic acid (5HIAA)) and catecholamines after dietary components had been changed. ${ }^{1 \sim 5)}$ Serotonin (5-hydroxytryptamine), a putative neurotransmitter in the mammalian central nervous system, is synthesized in the brain through the 5-hydroxylation and decarboxylation of the essential amino acid, Ltryptophan. ${ }^{6,7)}$ The enzyme that catalyzes this reaction, tryptophan 5-hydroxylase (EC 1.14.16.4), has a poor affinity for its amino acid substrate; hence, treatments that raise or lower the brain tryptophan level can easily affect the production of serotonin. ${ }^{8}$ Small doses of tryptophan cause a significant increase in the serotonin concentration in rat brain, ${ }^{8)}$ conversely, the chronic ingestion of a diet lacking in tryptophan depresses the brain serotonin level..$^{9 \sim 11}$ In the case of the ingestion of a low protein diet, the supplementation of a single essential amino acid, such as methionine, leucine, phenylalanine and isoleucine, caused significant decreases in brain 5hydroxyindoles, as to the competitive inhibition of these amino acids of tryptophan transport via the blood-brain barrier. ${ }^{2)}$ The supplementation of a limiting amino acid (methionine in a soy protein, lysine and tryptophan in a wheat gluten, or tryptophan in a gelatin diet) to a low protein diet also caused major neurochemical changes. ${ }^{12)}$

On the other hand, the administration of some xenobiotics, such as drugs and contaminants in the diet (BHA, chloretone, DDT

${ }^{\dagger}$ This work was supported by a Grant-in-Aid for Scientific Research from the Ministry of Education, Science and Culture of Japan.

* Address for correspondence: Laboratory of Nutritional Biochemistry, School of Food and Nutritional Science, The University of Shizuoka, 395 Yada, Shizuoka 422, Japan. 
or PCB), caused increases in the activity of the mixed function oxidase system, ${ }^{13}$ ) the excretion of urinary ascorbic acid ${ }^{14,15)}$ and the concentrations of serum lipids (cholesterol and triglyceride).$^{15,16)}$ Caffeine and caffeinecontaining beverages similarly elevated the activity of the mixed function oxidase system, and caused increases in serum cholesterol and urinary excretion of ascorbic acid. ${ }^{15,17)}$ Therefore, it is considered that caffeine is one of the xenobiotics, like BHA, chloretone, DDT and PCB, that induce some nutritional changes. On the other hand, neurochemical studies have shown that caffeine releases brain catecholamines, ${ }^{18}$ inhibits phosphodiesterase (EC 3.1.4.17) activity with the resultant accumulation of cyclic adenosine monophosphate (cAMP), acts as a competitive antagonist of adenosine receptors, ${ }^{19 \sim 21)}$ and also elevates the brain levels of tryptophan, serotonin and 5HIAA. ${ }^{22-24)}$ Therefore, some other xenobiotics might also change the levels of brain 5-hydroxyindoles or cAMP, like in the case of caffeine.

In the present study I examined whether or not the administration of some xenobiotics influences the disposition of brain 5-hydroxyindoles and catecholamines.

\section{Materials and Methods}

Animals and diets. Young male rats of the Wistar strain $(100 \sim 120 \mathrm{~g})^{* 1}$ were fed a $20 \%$ casein diet for 1 week for adaptation. The animals were injected with the drugs or fed the test diets and later decapitated (the times selected for killing animals after treatment are given for each experiment). Their brains were immediately removed, dissected, frozen on dry ice and then stored at $-70^{\circ} \mathrm{C}$ until assayed. Blood was collected from the cervical wound and serum samples were stored at $-20^{\circ} \mathrm{C}$ until assayed. The composition of the basal diet, containing $20 \%$ of casein, is shown in Table I. The same amount of carbohydrate as that of a xenobiotic was substituted. The room temperature was maintained at $24^{\circ} \mathrm{C}$ with a cycle of $12 \mathrm{hr}$ light
Table 1. Composition of Basal Diet

$\begin{array}{lr}\text { Casein }^{1} & 20.0 \\ \text { Carbohydrate }^{\prime} & 68.7 \\ \quad \text { (starch }: \text { sucrose }=2: 1) & \\ \text { Corn oil } & 5.0 \\ \text { Mineral mixture } & 5.0 \\ \text { Vitamin mixture }^{3} & 1.0 \\ \text { Choline-Cl } & 0.3\end{array}$

1 Casein, containing $87.9 \%$ crude proteins: Katayama Chemical Industries Co., Ltd., Osaka, Japan.

2 Mineral mixture (AIN-76 ${ }^{\mathrm{TM}}$ ) produced by Nihon Nosan Kogyo K.K., Yokohama, Japan.

3 Vitamin mixture (AIN-76 ${ }^{\mathrm{TM}}$ ) produced by Nihon Nosan Kogyo K.K., Yokohama, Japan.

(between 08:00 and 20:00) and $12 \mathrm{hr}$ dark. All rats were individually housed, provided with the diet and water ad libitum and weighed daily during the experimental period.

Experiment 1 . The effects of pentobarbital on brain 5hydroxyindoles were investigated. Rats were divided into two groups (five rats per group), which were intraperitoneally injected with saline or pentobarbital- $\mathrm{Na}(7.5 \mathrm{mg}$ per $100 \mathrm{~g}$ body weight), ${ }^{* 2}$ respectively. The animals were decapitated $5 \mathrm{hr}$ after the injection. The concentrations of serum and brain tryptophan were determined by the method of Denckla and Dewey. ${ }^{25)}$ Brain serotonin and 5HIAA were assayed fluorimetrically. ${ }^{26)}$

Experiment 2. The effects of some xenobiotics on brain 5-hydroxyindoles and serum cAMP were investigated. Rats were fed a $20 \%$ casein diet for $7 \mathrm{~d}$ and then divided into five groups (six rats per group). On the 8 th evening at $1700 \mathrm{hr}$, the rats were fed the test diets containing some xenobiotics for a $5 \mathrm{hr}$ period (between 1700 and $2200 \mathrm{hr}$ ) and decapitated at $2200 \mathrm{hr}$. The basal diet contained $20 \%$ casein and the test diets were prepared by the supplementation of $0.3 \% \mathrm{BHA}^{* 3} 0.1 \% \mathrm{DDT}^{* 4}$ and $0.03 \%$ $\mathrm{PCB},{ }^{* 5}$ respectively, to the basal diet. Tryptophan ${ }^{25)}$ in the serum and brain, and 5-hydroxyindoles ${ }^{26}$ in the brain were determined fluorimetrically. Serum cAMP concentrations were measured by means of a radioimmunoassay using anti-succinyl cAMP serum (cAMP-[ ${ }^{125}$ I]-assay system) $* 6$

Experiment 3. The effects of chloretone and/or some inhibitors of monoamine synthesis and degradation on

\footnotetext{
* Japan SLC Inc., Hamamatsu, Japan.

*2 Nembutal: Dainippon Pharmaceutical Co., Ltd., Osaka, Japan.

*3 3-tert-Butyl-4-methoxyphenol: Katayama Chemical Co., Ltd., Osaka.

*4 1,1-Bis-(p-chlorophenyl)-2,2,2-trichloroethane : Aldrich Chemical Co., Ltd., Milwaukee, Wisconsin.

*5 Polychlorinated biphenyls, Aroclor 1248: Mitsubishi Monsant Co., Ltd., Tokyo.

*6 Amersham Japan Ltd., Tokyo, Japan.
} 
brain 5-hydroxyindoles and hypothalamus catecholamines were investigated. Chloretone was dissolved in corn oil and then administered by oral intubation $(0.3 \mathrm{~g} / \mathrm{kg})$. Pargyline, ${ }^{* 7}$ an inhibitor of monoamine oxidase, was injected twice intraperitoneally, $1 \mathrm{hr}$ before $(50 \mathrm{mg} / \mathrm{kg})$ and $1 \mathrm{hr}$ after $(25 \mathrm{mg} / \mathrm{kg})$ the chloretone administration. $p$-Chlorophenylalanine (PCPA), an inhibitor of tryptophan hydroxylase, was injected twice intraperitoneally into the remaining rats, $1 \mathrm{hr}$ before $(200 \mathrm{mg} / \mathrm{kg})$ and $1 \mathrm{hr}$ after $(100 \mathrm{mg} / \mathrm{kg})$ the chloretone administration. Corn oil was also administered by intubation for placebotreatment. Rats were decapitated $1 \mathrm{hr}$ after the second inhibitor administration. Brain tryptophan ${ }^{25}$ and 5-hydroxyindoles, ${ }^{26)}$ and serum tryptophan ${ }^{25)}$ were determined by the same methods as in experiments 1 and 2 . Tyrosine was measured fluorimetrically by the method of Waalkes and Udenfriend. ${ }^{27)}$ The catecholamines (norepinephrine (NE) and dopamine (DA)) were purified on an alumina column and quantitated by reverse-phase high performance liquid chromatography with electrochemical detection. ${ }^{28), * 8}$

Statistical analysis. The statistical significance of the differences between values was determined by the Student $t$-test (experiment 1), and analysis of variance and Duncan's multiple range test ${ }^{29}$ (experiments 2 and 3 ).

\section{Results}

Effects of pentobarbital on brain 5-hydroxyindoles (Experiment 1)

When rats were injected with pentobarbital, $5 \mathrm{hr}$ later, the brain concentrations of serotonin and 5HIAA tended to be increased, compared to those in rats injected with saline
(Table II).

Effects of some xenobiotics on brain 5-hydroxyindoles and serum cAMP (Experiment 2)

When rats were fed a $\mathrm{BHA}$, chloretone or DDT-supplemented diet, the tryptophan concentration in the serum was significantly lower than when rats were fed the basal or PCBsupplemented diet (Table III). The concentrations of brain tryptophan in rats fed the test diets supplemented with xenobiotics were not different from that in the controls. The serotonin concentrations in the brains of rats fed the xenobiotic-supplemented diets were significantly higher than when rats were fed the basal diet, especially in the case of chloretone supplementation. The concentrations of brain 5HIAA also tended to increase (in the PCB and DDT-supplemented groups) or were significantly increased (in the BHA and chloretonesupplemented groups). The concentrations of serum CAMP in rats treated with xenobiotics were significantly increased as compared with those in rats fed the basal diet.

\section{Effects of chloretone and/or pargyline or PCPA} on brain 5-hydroxyindoles and catecholamines (Experiment 3)

In the previous experiment, 2, the effect of chloretone on brain 5-hydroxyindoles was found to be significant, therefore, in this ex-

Table II. EfFects of Pentobarbital on Brain Tryptophan and 5-Hydroxyindoles IN RATS (EXPERIMENT 1) ${ }^{1}$

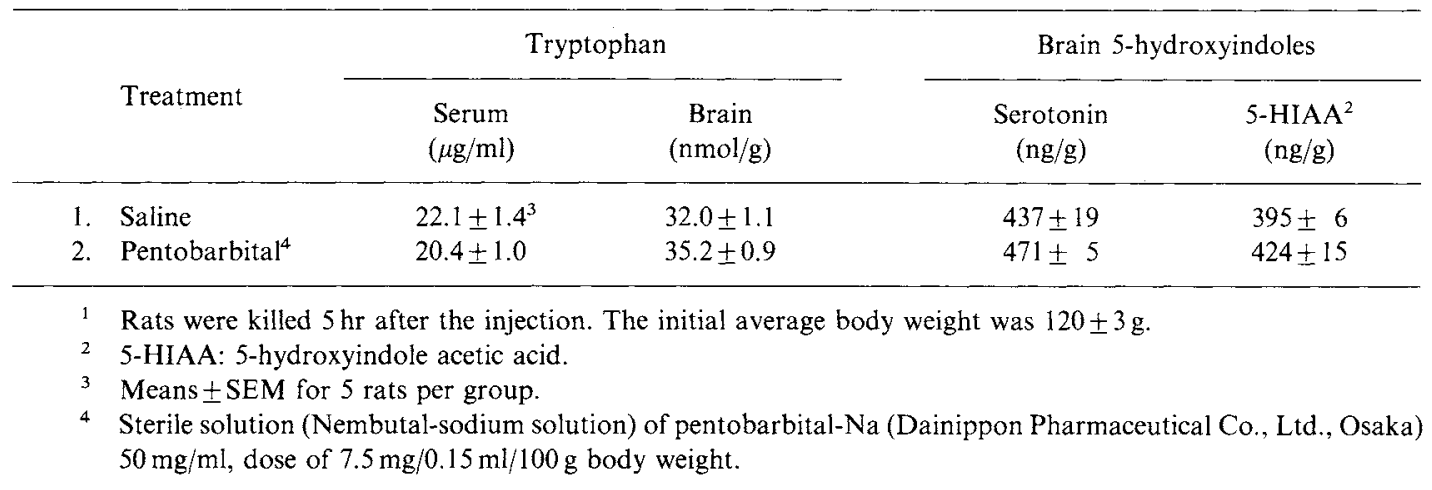

*7 Sigma Chemical Co., St. Louis, MO.

*8 L-3200V: Yanagimoto Mfg. Co., Ltd., Kyoto, Japan. 
Table III. EfFects of BHA, Chloretone, DDT and PCB on Brain 5-Hydroxyindoles and Serum c-AMP in Rats (Experiment 2) ${ }^{\mathrm{i}}$

\begin{tabular}{|c|c|c|c|c|c|c|}
\hline & \multirow[b]{2}{*}{ Diet } & \multicolumn{2}{|c|}{ Tryptophan } & \multicolumn{2}{|c|}{ Brain 5-hydroxyindoles } & \multirow{2}{*}{$\begin{array}{c}\text { Serum } \\
\text { c-AMP } \\
(\mathrm{nmol} / \mathrm{ml})\end{array}$} \\
\hline & & $\begin{array}{l}\text { Serum } \\
(\mu \mathrm{g} / \mathrm{ml})\end{array}$ & $\begin{array}{c}\text { Brain } \\
(\mathrm{nmol} / \mathrm{g})\end{array}$ & $\begin{array}{l}\text { Serotonin } \\
(\mathrm{ng} / \mathrm{g})\end{array}$ & $\begin{array}{c}\text { 5- } \mathrm{HIAA}^{2} \\
(\mathrm{ng} / \mathrm{g})\end{array}$ & \\
\hline 1. & $20 \%$ Casein & $29.7 \pm 1.3^{3.2}$ & $32.9 \pm 1.4$ & $535 \pm 5^{\mathfrak{c}}$ & $334 \pm 7^{b}$ & $38.3 \pm 2.0^{c}$ \\
\hline 2. & $0.3 \% \mathrm{BHA}^{4}$ & $25.5 \pm 1.2^{\mathrm{b}}$ & $32.3 \pm 0.9$ & $588 \pm 9^{b}$ & $395 \pm 16^{a}$ & $43.8 \pm 2.0^{\mathrm{b}}$ \\
\hline 3. & $0.3 \%$ Chloretone 5 & $24.9 \pm 0.6^{\mathrm{b}}$ & $35.3 \pm 2.3$ & $643 \pm 7^{a}$ & $396 \pm 13^{\mathrm{a}}$ & $43.6 \pm 1.0^{b}$ \\
\hline 4. & $0.1 \% \mathrm{DDT}^{6}$ & $24.2 \pm 1.0^{\mathrm{b}}$ & $34.3 \pm 2.0$ & $595 \pm 12^{b}$ & $365 \pm 17^{\mathrm{ab}}$ & $43.6 \pm 1.6^{b}$ \\
\hline 5 . & $0.03 \% \mathrm{PCB}^{7}$ & $29.3 \pm 1.2^{\mathrm{a}}$ & $34.1 \pm 1.6$ & $595 \pm 12^{b}$ & $354 \pm 9^{b}$ & $49.2 \pm 1.6^{\mathrm{a}}$ \\
\hline
\end{tabular}

1 Rats were killed $5 \mathrm{hr}$ after feeding the test diet. The initial average body weight was $124 \pm 3 \mathrm{~g}$.

2 5-HIAA: 5-hydroxyindole acetic acid.

3 Means \pm SEM for 6 rats per group. Means within a column not followed by the same letter are significantly different, Duncan's test $(p<0.05)$.

4 BHA, 3-tert-butyl-4-methoxyphenol: Katayama Chemical Co., Ltd., Osaka.

5 Chloretone, acetone chloroform: Katayama Chemical Co., Ltd., Osaka.

6 DDT, 1,1-bis-( $p$-chlorophenyl)-2,2,2-trichloroethane: Aldrich Chemical Co., Ltd., Milwaukee, Wisconsin.

PCB, polychlorinated biphenyls, Arocior 1248: Mitsubishi Monsant Co., Ltd., Tokyo.

periment, the direct effect of chloretone, which was not included in the diet, was investigated. When rats were intubated with chloretone, the concentrations of brain serotonin and 5HIAA were significantly increased as compared with those in rats intubated with the placebo (Table IV). When rats were injected with pargyline, the serotonin concentrations increased and the 5HIAA concentrations decreased significantly, as compared with those in the controls. Chloretone plus pargyline caused signifcant elevation of brain 5HIAA as compared to in the pargyline control, however, the concentration of brain serotonin was not different between pargyline alone and chloretone plus pargyline. PCPA caused significant decreases in brain serotonin and 5HIAA, as compared to in a placebo control. Chloretone plus PCPA caused significant elevation of brain serotonin and 5HIAA as compared to in the PCPA control.

On the other hand, when rats received chloretone, the concentrations of tyrosine, $\mathrm{NE}$ and DA in the hypothalamus were not different from those in the controls. Pargyline administration caused significant increases in NE and DA, and, furthermore, chloretone plus pargyline caused elevation of hypothalamus NE and DA, as compared to in the pargyline control.

\section{Discussion}

The effects of some xenobiotics, which enhance the mixed function oxidase system, on brain 5-hydroxyindoles and catecholamines were investigated. The administration of pentobarbital (Table II), BHA, chloretone, DDT and PCB (Table III) caused significant elevation of brain serotonin or a tendency for it to increase and, in some cases, also a rapid increase of 5HIAA ( $5 \mathrm{hr}$ after xenobiotic administration). This phenomenon of increased brain serotonin levels caused by xenobiotics may resemble the increase in brain serotonin concentration on the administration of insulin, because, in both cases, the acceleration of protein synthesis (mixed function oxidase system after xenobiotic administration ${ }^{30)}$ or peripheral protein synthesis after insulin administration ${ }^{317}$ ) participates in these increases in brain serotonin; that is, the changes in the pattern of plasma large neutral amino acids (such as phenylalanine, tyrosine, leucine, isoleucine, valine and threonine) caused by the acceleration of amino acid utilization for protein synthesis affect the entry of tryptophan across the blood-brain barrier and serotonin 
Table IV. Effects of Chloretone Administration with or without Pargyline or $p$-Chlorophenylalanine (PCPA) on Brain 5-Hydroxyindoles and Hypothalamic Catecholamines (Experiment 3) ${ }^{1}$

\begin{tabular}{|c|c|c|c|c|c|c|c|c|}
\hline & \multirow[b]{2}{*}{ Treatment } & \multicolumn{2}{|c|}{ Tryptophan } & \multicolumn{2}{|c|}{ Brain 5-hydroxyindoles } & \multicolumn{3}{|c|}{ Hypothalamus } \\
\hline & & $\begin{array}{l}\text { Serum } \\
(\mu \mathrm{g} / \mathrm{ml})\end{array}$ & $\begin{array}{c}\text { Brain } \\
(\mathrm{nmol} / \mathrm{g})\end{array}$ & $\begin{array}{l}\text { Serotonin } \\
(\mathrm{ng} / \mathrm{g})\end{array}$ & $\begin{array}{l}\text { 5-HIAA } \\
\text { (ng/g) }\end{array}$ & $\begin{array}{c}\text { Tyrosine } \\
(\mu \mathrm{g} / \mathrm{g})\end{array}$ & $\begin{array}{l}\text { Norepinephrine } \\
\qquad(\mu \mathrm{g} / \mathrm{g})\end{array}$ & $\begin{array}{c}\text { Dopamine } \\
(\mu \mathrm{g} / \mathrm{g})\end{array}$ \\
\hline 1. & Placebo & $18.3 \pm 0.8^{3 . b}$ & $31.5 \pm 1.6^{\mathrm{a}}$ & $509 \pm 3^{c}$ & $367 \pm 8^{b}$ & $11.9 \pm 1.1^{\mathrm{a}}$ & $1.00 \pm 0.11^{c}$ & $0.24 \pm 0.02^{\mathrm{d}}$ \\
\hline 2. & Chloretone ${ }^{4}$ & $11.8 \pm 1.0^{\mathrm{cd}}$ & $30.1 \pm 3.3^{\mathrm{a}}$ & $583 \pm 11^{b}$ & $416 \pm 15^{\mathrm{a}}$ & $13.0 \pm 1.2^{\mathrm{a}}$ & $1.02 \pm 0.11^{\mathrm{c}}$ & $0.29 \pm 0.03^{\mathrm{cd}}$ \\
\hline 3. & Pargyline $^{5}$ & $21.5 \pm 0.6^{\mathrm{a}}$ & $31.0 \pm 1.0^{\mathrm{a}}$ & $871 \pm 16^{\mathrm{a}}$ & $128 \pm 5^{e}$ & $5.5 \pm 1.1^{b}$ & $1.37 \pm 0.17^{b}$ & $0.64 \pm 0.08^{\mathrm{b}}$ \\
\hline 4. & Chloretone + Pargyline & $11.7 \pm 0.3^{\mathrm{cd}}$ & $27.4 \pm 0.9^{\mathrm{a}}$ & $850 \pm 14^{\mathrm{a}}$ & $164 \pm 8^{d}$ & $7.2 \pm 0.8^{\mathrm{b}}$ & $1.97 \pm 0.09^{\mathrm{a}}$ & $0.86 \pm 0.05^{\mathrm{a}}$ \\
\hline 5. & $\mathrm{PCPA}^{6}$ & $13.5 \pm 0.7^{\mathrm{c}}$ & $32.1 \pm 1.1^{\mathrm{a}}$ & $448 \pm 11^{\mathrm{d}}$ & $306 \pm 6^{c}$ & $6.1 \pm 0.8^{b}$ & $0.94 \pm 0.06^{\mathrm{c}}$ & $0.29 \pm 0.09^{\mathrm{cd}}$ \\
\hline 6. & Chloretone + PCPA & $10.6 \pm 0.5^{\mathrm{d}}$ & $30.5 \pm 0.7^{\mathrm{a}}$ & $520 \pm 10^{c}$ & $344 \pm 9^{b}$ & $6.3 \pm 1.0^{\mathrm{b}}$ & $1.06 \pm 0.09^{b c}$ & $0.46 \pm 0.10^{\mathrm{bc}}$ \\
\hline
\end{tabular}

1 The initial average body weight was $108 \pm 2 \mathrm{~g}$.

5-HIAA: 5-hydroxyindole acetic acid

3 Means \pm SEM for 6 rats per group. Means within a column not followed by the same letter are significantly different, Duncan's test ( $p<0.05)$.

4 Chloretone, acetone chloroform, $300 \mathrm{mg}$ per $\mathrm{kg}$ body weight, orally: Katayama Chemical Co., Ltd., Osaka.

5 Pargyline: pargyline (Sigma Chemical Co., St. Louis, MO) was injected twice intraperitoneally, $1 \mathrm{hr}$ before $(50 \mathrm{mg} / \mathrm{kg})$ and $1 \mathrm{hr}$ after (25 $\mathrm{mg} / \mathrm{kg}$ ) the chloretone administration.

6 PCPA: p-chlorophenylalanine (Sigma Chemical Co., St. Louis, MO) was injected twice intraperitoneally, $1 \mathrm{hr}$ before $(200 \mathrm{mg} / \mathrm{kg})$ and $1 \mathrm{hr}$ after (100 $\mathrm{mg} / \mathrm{kg})$ the chloretone administration. 
synthesis. $^{32 \sim 38)}$

The administration of caffeine $e^{22-24)}$ and caffeine-containing beverages $^{23}$ to rats increases the concentrations of serotonin and 5HIAA in the brain. Berkowitz and Spector reported that the increase in brain serotonin content following caffeine administration could be due to the prevention of brain serotonin release or increased serotonin synthesis. ${ }^{22)}$ Aminophylline also elevated the brain tryptophan and 5HIAA levels. ${ }^{39)}$ The mechanisms underlying these actions were not explored in detail (e.g., blockading of an adenosine receptor and/or inhibition of phosphodiesterase). As it was known that caffeine inhibits phosphodiesterase activity with the resultant accumulation of $\mathrm{CAMP},{ }^{40,41)}$ in this experiment, the concentrations of serum cAMP after the administration of some xenobiotics were determined. The xenobiotics tested elevated the serum cAMP level. However, it is unclear why these xenobiotics changed the serum cAMP level.

In the next experiment, I determined the mechanism underlying these changes in brain serotonin and 5HIAA levels by using pargyline or PCPA, in the case of the administration of chloretone as an example of the xenobiotics. If chloretone elevates the serotonin level by accelerating its synthesis through the major pathway, which involves tryptophan hydroxylase, the concentration of brain serotonin on exposure to chloretone plus pargyline would be expected to increase more than in the case of pargyline alone. On the other hand, if the major pathway for the metabolism of serotonin is deamination by monoamine oxidase, and chloretone also elevates the serotonin level by preventing its metabolism through the major degradative pathway, which involves monoamine oxidase, the concentration of the metabolic product of this reaction, 5HIAA, would be expected to decrease. To minimize the contribution of serotonin synthesis I employed PCPA, which is known to prevent synthesis at the tryptophan hydroxylase step. ${ }^{42)}$ As can be seen in Table IV, the concentration of brain serotonin was not different between pargyline alone and chloretone plus pargyline, however, chloretone plus PCPA caused significant elevation of brain serotonin and 5HIAA as compared to in the PCPA control. Also, the increase in brain 5HIAA level caused by chloretone plus PCPA may be due to the reduced removal of 5HIAA from the brain or the reduced degradation of 5HIAA, as compared to in the PCPA control. Therefore, the increase in the brain serotonin level caused by chloretone is not due to the acceleration of brain serotonin synthesis, but to retardation of the degradation of brain serotonin. On the other hand, as chloretone plus pargyline caused significant elevation of brain 5HIAA, as compared to in the pargyline control, the mechanism underlying the increase in brain 5HIAA level caused by chloretone may be due to the reduced removal of 5HIAA from the brain by the acid transport system.

The administration of chloretone did not affect the endogenous levels of tyrosine, NE and DA in the hypothalamus. However, as can be seen in Table 4, following the blockading of monoamine oxidase, chloretone plus pargyline caused significant elevation of hypothalamus $\mathrm{NE}$ and DA, as compared to in the pargyline control. Therefore, these results show that the catecholamine turnover rates (synthesis and degradation) may be accelerated by the administration of chloretone. Further experimentation is required to explain this disparity.

Here, I investigated the effects of exposure to many kinds of xenobiotics, such as food additives, contaminants, drugs, foreign compounds, etc., in the diet. Also, it is well known that some xenobiotics affect hepatic drugmetabolizing systems, ${ }^{13)}$ the metabolism of fat soluble or water soluble vitamins, ${ }^{13 \sim 15)}$ lipid or protein metabolism and so on. ${ }^{15 \sim 17)}$ These xenobiotics may cause not only biochemical changes in the body but also affect neurochemical compounds in the brain, and may also induce some behavioral changes. The possibility of changes in neurotransmitters caused by some xenobiotics was proposed. The relationship between nutrition (diet) and be- 
havior will be studied in the near future.

\section{References}

1) H. Yokogoshi and R. J. Wurtman, Metabolism, 35, 837 (1986).

2) H. Yokogoshi, T. Iwata, K. Ishida and A. Yoshida, J. Nutr., 117, 42 (1987).

3) H. Yokogoshi, T. Iwata and K. Ishida, Nutr. Rep. Int., 34, 207 (1986).

4) H. Yokogoshi, K. Ishida and T. Iwata, Nutr. Rep. Int., 32, 405 (1987).

5) H. Yokogoshi, Nutr. Rep. Int., 32, 405 (1985).

6) W. Lovenberg, E. Jequier and A. Sjoerdsma, $A d v$. Pharmacol., 6A, 21 (1968).

7) W. Lovenberg, H. Weissbach and S. Udenfriend, $J$. Biol. Chem., 237, 89 (1962).

8) J. D. Fernstrom and R. J. Wurtman, Science, 173, 149 (1971).

9) G. Zbinden, A. Pletscher and A. Studer, Z. Gesamte Exp. Med., 129, 615 (1958).

10) E. M. Gal and P. A. Drewes, Proc. Soc. Exp. Biol. Med., 110, 368 (1962).

11) W. J. Culley R. N. Saunders, E. T. Mertz and D. H. Jolly, Proc. Soc. Exp. Biol. Med., 113, 645 (1962).

12) H. Yokogoshi, T. Iwata and K. Ishida, Agric. Biol. Chem., 52, 701 (1988).

13) N. Kato, M. Kato, T. Kimura and A. Yoshida, Nutr. Rep. Int., 18, 437 (1978).

14) A. H. Conny and J. J. Burns, Nature (London), 184, 363 (1959).

15) S. Quazi, M. Takahata, H. Yokogoshi and A. Yoshida, Agric. Biol. Chem., 48, 1581 (1984).

16) N. Kato and A. Yoshida, Nutr. Rep. Int., 23, 825 (1981)

17) H. Yokogoshi, S. Mochizuki, M. Takahata, S. Quazi and A. Yoshida, Nutr. Rep. Int., 28, 805 (1983).

18) B. A. Berkowitz, J. R. Tarver and S. Spector, Eur. J. Pharmacol., 10, 64 (1970).

19) J. W. Daly, R. F. Bruns and S. H. Snyder, Life Sci., 28, 2083 (1981).

20) S. H. Snyder, J. J. Katims, Z. Annau, R. F. Bruns and J. W. Daly, Proc. Natl. Acad. Sci. U.S.A., 78,
3260 (1981).

21) K. M. M. Murphy and S. H. Snyder, Mol. Pharmacol., 22, 250 (1982).

22) A. Berkowitz and S. Spector, Eur. J. Pharm., 16, 322 (1971).

23) H. Yokogoshi, S. Tani and N. Amano, Agric. Biol. Chem., 51, 3281 (1987).

24) M. H. Fernstrom, C. W. Bazil and J. D. Fernstrom, Life Sci., 35, 1241 (1984).

25) W. D. Denckla and H. K. Dewey, J. Lab. Clin. Med., 69, 160 (1967).

26) J. H. Thompson, CH. A. Spezia and M. Agnulo, Experientia, 26, 327 (1970).

27) T. P. Waalkes and S. Udenfriend, J. Lab. Clin. Med., 50, 733 (1957).

28) J. L. Felice, J. D. Felice and P. T. Kissinger, J. Neurochem., 31, 1461 (1978).

29) D. B. Duncan, Biometrics, 13, 164 (1957).

30) A. H. Conney and J. J. Burns, Nature, 184, 363 (1959).

31) V. M. Pain and P. J. Garlick, J. Biol. Chem., 249, 4510 (1974).

32) J. D. Fernstrom and R. J. Wurtman, Science, 178, 414 (1975).

33) R. J. Wurtman and J. D. Fernstrom, Am. J. Clin. Nutr., 28, 638 (1975).

34) J. D. Fernstrom, F. Larin and R. J. Wurtman, Life Sci., 13, 517 (1973).

35) R. J. Wurtman and J. D. Fernstrom, Biochem. Pharmacol., 25, 1691 (1976).

36) J. D. Fernstrom and D. V. Faller, J. Neurochem., 30, 1531 (1978).

37) W. M. Pardridge, in "Nutrition and the Brain" ed. by R. J. Wurtman and J. J. Wurtman, Raven Press, New York, 1977, p. 141.

38) W. M. Pardridge and W. H. Oldendorf, Biochim. Biophys. Acta, 401, 128 (1975).

39) D. P. Cardinali, Eur. J. Pharmacol., 47, 239 (1978).

40) R. W. Butcher and E. W. Sutherland, J. Biol. Chem., 237, 1244 (1962).

41) W. Y. Cheung, Biochemistry, 61079 (1967).

42) B. K. Koe and A. Weissman, J. Pharmacol. Exptl. Therap., 154, 499 (1966). 